\title{
Delay Function in Dependence of Dynamic Phenomena
}

\author{
V. Valentová*, J. Novák \\ Division of Road Safety and Traffic Engineering, Transport Research Centre, Brno \\ *Corresponding author: veronika.valentova@cdv.cz
}

DOI: 10.2478/trans-2014-0001

\begin{abstract}
Knowledge of actual road traffic volume and road capacity is a part of the data necessary to know when an emergency event occurs and the traffic needs to be quickly diverted to an alternative route. The method based on Czech standards for calculating traffic volume and capacity was innovated. The first step of the method deals with the determination of road capacity depending on its category and traffic volume. The other part of the method takes into account the calculation with adverse weather conditions, such as rain or snow, low temperature and bad visibility. The latter part is derived from international studies. The actual capacity method is used in a new assistance system for emergency services which is being developed by the Division of Road Safety and Traffic Engineering of Transport Research Centre in cooperation with the Police of the Czech Republic.
\end{abstract}

KEYWORDS: Traffic volume, capacity, delay function, adverse weather.

\section{INTRODUCTION}

Decisions about alternative routes which are made by the Police every time a traffic accident occurs have to be quick and alternative routes have to reflect the actual traffic volume. Making this decision is not easy, especially in adverse weather conditions and in winter. A new assistance system which is developed by Transport Research Centre, in cooperation with the Police of the Czech Republic, is going to help in these difficult situations. The system collects data from different sources and contains e. g. information on locations of emergency vehicles, gritting vehicles, information from police databases NDIC (National Traffic Information Centre), CDI2 (localized traffic information) and on meteorological situation. For computing of traffic volume and capacity the data from SDB (road database operated by Road and Motorway Directorate of the Czech Republic) will be used. This data contains information on road parameters in the Czech Republic, such as a category of road, segment length, width and number of lanes.

The main objective of the paper is to determine time delay on a road segment. The time delay needs to take into account the dynamic factors of traffic flow. The delay function should include the effect of traffic volume and influence of adverse weather conditions on road capacity. Although actual volume assessment is implemented into the project according to Czech standards (ČSN 73 6101, 2009; TP 189, 2012; TP 225, 2010), road capacity in different weather conditions has no support in Czech standards. The factors used in the project are derived from international studies. Only significantly influencing parameters (precipitation, temperature, reduced visibility) were used in the calculation. 


\section{DELAY FUNCTION}

In case of a road accident, an area restriction or a traffic closure is employed. In such situations it is necessary to consider using road diversions. The traffic flow is moved from the original route to a temporary one, which has to be evaluated in order to guarantee smooth traffic diversion.

Czech standards classify the road network into seven categories. Each category has different traffic engineering parameters and is able to provide various levels of service. These parameters need to be collected and assessed so that the temporarily diverted traffic runs smoothly.

Parameters, such as road category, section length, number and width of lanes, slope or respective traffic volume can be searched or derived from the road databank of the Czech Republic. Those parameters are essential to define the capacity of each road section. The calculation of the capacity setting is defined by Czech standards (ČSN 73 6101, 2009). On the other hand, the loss of travel time is not. And it is mostly this parameter which determines the driver's satisfaction.

Foreign literature (Ortúzar \& Willumsen, 2011) states that the calculation of travel time between two points depends on road traffic volume and capacity. Free travel time means a time period during which a vehicle is moving between points 1 and 2 with no outside distractions. This is, however, impossible in reality. The calculation is therefore corrected by increasing the travel time by adding the time influenced by capacity and traffic volume.

$$
S_{a}=t_{a} \cdot\left(1+\alpha\left(\frac{I_{a}}{C_{a}}\right)^{\beta}\right)
$$

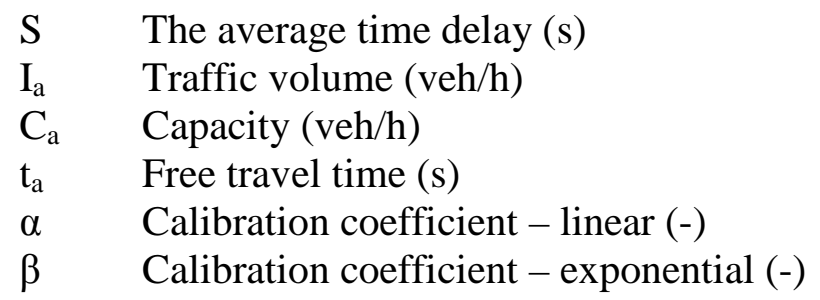

The model of the Bureau of Public Roads (Ortúzar \& Willumsen, 2011) is the most suitable for the average travel time loss for road sections in the Czech Republic. Since it is the only one which considers seven roads categories on Czech road network (Interstate, limited Access Highway, principal Arterial, Minor Arterial, Major collector, Rural major Collector, Urban local).

This model was experimentally verified in the USA on 37 junctions and road sections (Jeihani, Lawe \& Conolly, 2006). Figure 1 shows the dependence of individual time losses on traffic volume, with regard to the calibration parameters of each road category ( $\alpha$ and $\beta$ ).

The model of the Bureau of Public Roads considers the time loss with two-component exponential growth. The first component contains the time loss only in free or zero traffic volume. The other component covers the exponential growth in dependence on the ratio between traffic volume and capacity on the section sections. Coefficients $\alpha$ and $\beta$ are parameters of the growth curve. For example, using speed V $=80 \mathrm{~km} / \mathrm{h}$, volume 1000 $\mathrm{veh} / \mathrm{h}$ and capacity $1200 \mathrm{veh} / \mathrm{h}$, the model yields time loss of approx. 110 second. 


\section{Time delay on roads $\mathbf{C Z}$}

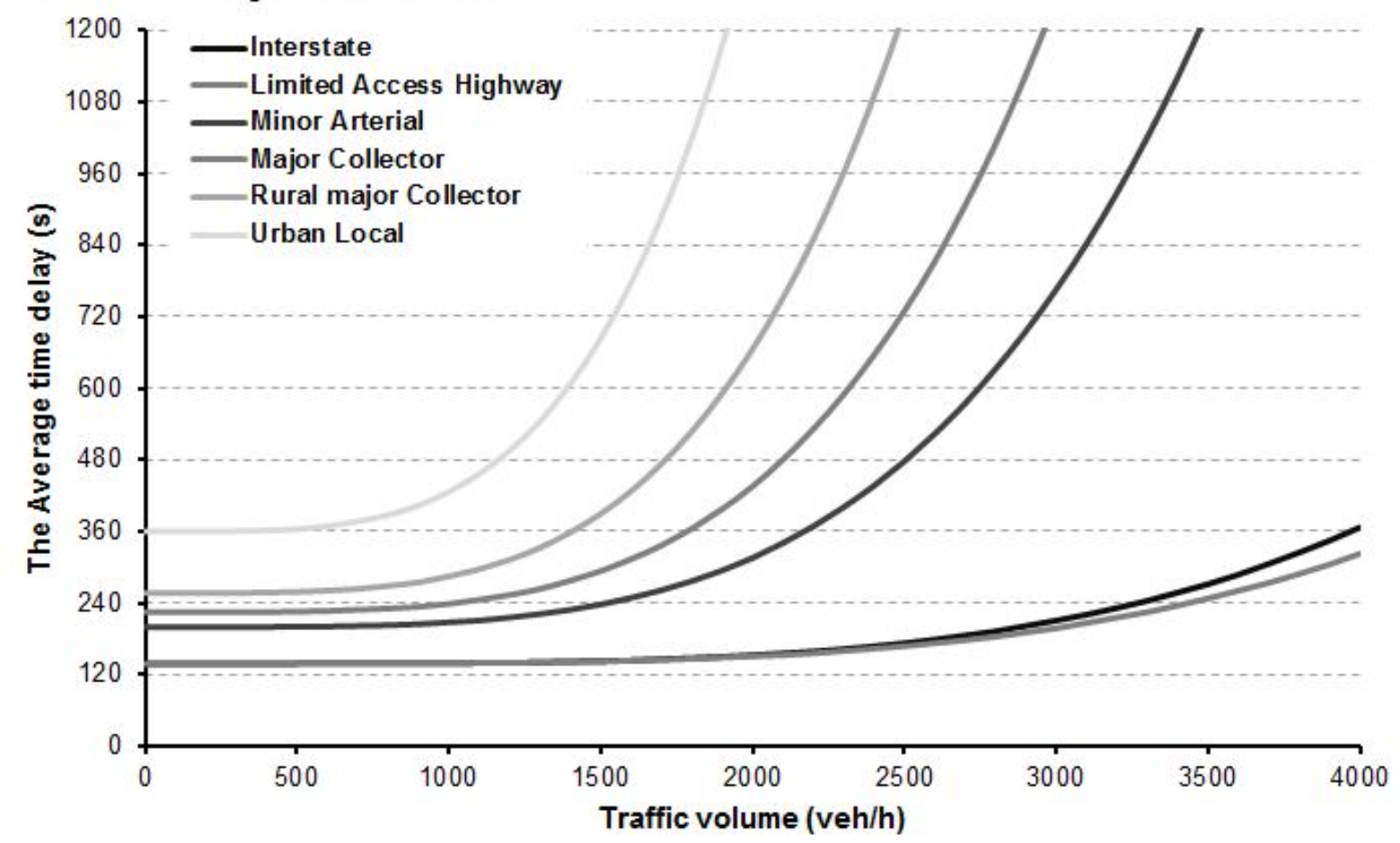

Figure 1: Time delay on czech roads.

The result is then the average time of vehicle ride from point 1 to point 2 . The calibration parameters $\alpha$ and $\beta$ may be adjusted for every road category. Furthermore, it is recommended to take into consideration two-way traffic because there may be changes in the traffic volume or other unexpected occurrences in both cases. The following Table 1 contains the list of input values for the calculation of medium time delay according to Czech standards. Speeds are chosen with regard to road category speed limit. Coefficients $\alpha$ and $\beta$ are taken from studies which consider the same roads categories like in Czech Republic. The road section capacity of a given road category is chosen according to table values of Czech standards.

Table 1: Input parameters for the delay function.

\begin{tabular}{|c|c|c|c|c|c|c|c|c|}
\hline & 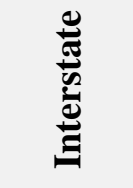 & 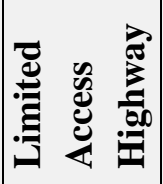 & 氞 & 旁营 & 泀 & 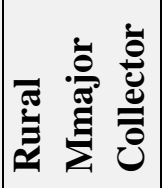 & 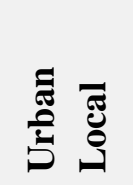 & $(-)$ \\
\hline Speed & 130 & 130 & 90 & 90 & 90 & 90 & 50 & $(\mathrm{~km} / \mathrm{h})$ \\
\hline Distance in $1 \mathrm{~s}$ & 36.11 & 36.11 & 25.00 & 25.00 & 22.22 & 19.44 & 13.89 & (m) \\
\hline $\begin{array}{l}\text { Minimal time delay } \\
t_{a}\end{array}$ & 138.47 & 138.47 & 200.00 & 200.00 & 225.02 & 257.20 & 359.97 & (s) \\
\hline $\begin{array}{l}\text { Capacity according } \\
\text { to ČSN } 736101\end{array}$ & 4000 & 4000 & 3600 & 2500 & 2165 & 2050 & 2500 & (veh/h) \\
\hline$\alpha$ & 1.65 & 1.33 & 1.10 & 1.39 & 1.28 & 1.75 & 6.60 & $(-)$ \\
\hline$\beta$ & 4.00 & 3.90 & 3.90 & 3.90 & 3.90 & 3.90 & 3.90 & $(-)$ \\
\hline
\end{tabular}


It is useful to integrate the variable traffic volume into the model. Traffic volume is heavily influenced by the time of day as well as traffic demand. Traffic demand is not observed in this project but the daytime is. Traffic volume is converted to AADT based on TP 189 standard (2012) and after that back to the demanded day and hour.

The overall result of the delay function should be the medium time delay on the diverted route taking into consideration variable traffic volume, road category (capacity) and the relevant vehicles speed. The next step of the calculation of road capacity takes into consideration the weather influence (rain, snow, temperature), too.

\section{INFLUENCE OF SIGNIFICANT FACTORS OF ADVERSE WEATHER CONDITIONS ON ROAD CAPACITY}

The first studies of the influence of weather on road capacity appeared in the 1950s (Tanner, 1952). Adverse weather conditions reduce road capacity, but the specific value differs in each country worldwide, depending on geographic location. Drivers are used to drive in specific weather conditions. For example in areas with high precipitation, there will be bigger decrease in capacity compared to the area with low precipitation. The reason is that the drivers in the latter group do not adapt well to changes in conditions such as worse adhesion or longer breaking distances. They drive with higher risk not being aware of it. The drivers of the former group, in areas with higher precipitation, are aware of the risks, they slow down and maintain greater distances between each other.

Differences in speed and capacity were observed depending on the day of week, too. At weekdays, the decrease is lower than at weekends. The decrease is also higher at night. This is probably caused by different levels of risk which drivers take for different reasons of trips and by the value of time in different times.

The observed decrease of capacity is empirical in studies under consideration. It is sometimes possible to find an equation, but it also only depends on empirical data (Alhassan \& Johnnie, 2011; Chung et al., 2006; Hranac et al., 2006; National Academic Press, 2004; HCM, 2010).

Regarding the differences between studies, the values used in the project were rounded to five per cent. The values lower than five per cent were removed. In the end, only the effect of precipitation, low temperature and reduced visibility were used.

It is only possible to use the percentage of decrease showed in the tables below for macroscopic models. These values are derived from the studies produced in the USA, in Germany, Great Britain and Japan. For smaller scale models it is inevitable to make measurements in specific localities.

The values are divided according to the amount of precipitation in each region into three groups. The scale used for the classification has eight degrees in accordance with the rain map, snow map and the climate map (temperature) of the Czech Republic (ČSN EN 1991-1-3, 2012; Český hydrometeorologický ústav, 2012). 
Table 2: Precipitation groups of regions of the Czech Republic.

\begin{tabular}{|lc|}
\hline Group 1 - below average rainfall & The average value on a scale 1-8 \\
\hline Region & 2.8 \\
\hline Ústí nad Labem Region & 2.0 \\
Plzeň Region & 3.0 \\
Pardubice Region & 2.7 \\
South Bohemia Region & 1.7 \\
Central Bohemia Region & 1.6 \\
South Moravia Region & 1.0 \\
Prague Region & \\
\hline Group 2 - average rainfall & 3.5 \\
\hline North Moravia Region & 3.5 \\
Vysočina Region & 3.6 \\
Olomouc Region & 3.4 \\
Zlín Region & \\
\hline Group 3 - extreme rainfall & 4.0 \\
\hline Karlovy Vary Region & 4.3 \\
Hradec Králové Region & 5.3 \\
Liberec Region & \\
\hline
\end{tabular}

Table 3: Percentage reduction in road capacity due to precipitation at different times of day and different days of week.

\begin{tabular}{|c|c|c|c|c|c|}
\hline $\begin{array}{c}\text { Amount of } \\
\text { precipitation }\end{array}$ & Group & $\begin{array}{l}\text { Weekday } \\
\text { daylight }\end{array}$ & $\begin{array}{c}\text { Week day } \\
\text { night }\end{array}$ & $\begin{array}{l}\text { Weekend } \\
\text { daylight }\end{array}$ & $\begin{array}{c}\text { Weekend } \\
\text { night }\end{array}$ \\
\hline \multicolumn{6}{|l|}{ Rain } \\
\hline \multirow[t]{3}{*}{$1-10 \mathrm{~mm} / \mathrm{h}$} & 1 & 10 & 25 & 20 & 25 \\
\hline & 2 & 10 & 30 & 20 & 30 \\
\hline & 3 & 10 & 40 & 20 & 40 \\
\hline \multirow{3}{*}{$\begin{array}{l}\text { Over } \\
10 \mathrm{~mm} / \mathrm{h}\end{array}$} & 1 & 15 & 25 & 30 & 35 \\
\hline & 2 & 20 & 35 & 35 & 40 \\
\hline & 3 & 20 & 40 & 40 & 40 \\
\hline \multicolumn{6}{|l|}{ Snow } \\
\hline \multirow[t]{3}{*}{$1-10 \mathrm{~mm} / \mathrm{h}$} & 1 & 10 & 25 & 20 & 25 \\
\hline & 2 & 15 & 30 & 20 & 30 \\
\hline & 3 & 25 & 40 & 40 & 40 \\
\hline \multirow{3}{*}{$\begin{array}{l}\text { Over } \\
10 \mathrm{~mm} / \mathrm{h}\end{array}$} & 1 & 15 & 30 & 30 & 35 \\
\hline & 2 & 20 & 35 & 35 & 40 \\
\hline & 3 & 25 & 40 & 40 & 40 \\
\hline
\end{tabular}

\subsection{Precipitation}

The actual precipitation situation is drawn from the meteorological radar data. A figure of the updated situation is published every 10 minutes on a specialized server operated by the Czech Hydrometeorological Institute (Český hydrometeorologický ústav, 2012). 
The figure is analysed by RGB detection in a defined area (where the traffic issue occurs) and the intensity of the rainfall or snow is recognized according to the colour scale. The day of week and daytime are analysed and in the last step the value from Table 2 is used for reducing of the road capacity.

Daylight and night are calculated with the use of an algorithm for dealing with sunrise and sunset. The algorithm is developed by Jarmo Lammi, published in Scout Report for Science \& Engineering in 1997.

\subsection{Temperature}

The influence of temperature is not as crucial as the influence of precipitation. There was observed a reduction in capacity by a several percentage points. Only in case temperature is really low, it becomes more significant. In the project, only temperature lower than $-20{ }^{\circ} \mathrm{C}$ is used, see Table 4 . The data and method used for the assessment of the current temperature are the same as for precipitation.

Table 4: Percentage reduction in road capacity due to low temperature.

\section{Temperature}

\begin{tabular}{|l|l}
$<-20^{\circ} \mathrm{C}$ & 10
\end{tabular}

\subsection{Reduced visibility}

The last weather factor which is a part of the used calculations is reduced visibility. In this group the influence of night on dry road and the influence of fog and possibly of smoke are included. The data for identification of fog are drawn from a website operated by Road and Motorway Directorate of the Czech Republic (RSD), which contains updated data from meteorological stations. The network of the data is rather sparse, so there will be a chance to enter it manually by a police officer. Data for night are calculated with the use of the algorithm described in paragraph 3.1.

Table 5: Percentage reduction in road capacity due to reduced visibility.

\begin{tabular}{|l|c|c|}
\hline Reduction of visibility & Weekday & Weekend \\
\hline Lighting conditions & 20 & 25 \\
\hline Night, dry road surface & \multicolumn{2}{|l|}{} \\
\hline Fog, smoke, etc. & \multicolumn{2}{|l|}{10} \\
\hline $\begin{array}{l}\text { For any detection (regardless } \\
\text { of the degree of reduction in } \\
\text { visibility) }\end{array}$ & \multicolumn{2}{|l|}{} \\
\hline
\end{tabular}

\section{CONCLUSION}

The assessment of the actual road capacity is important in situations when traffic needs to be transferred from higher class roads to lower class roads due to emergency events. This can cause a new traffic issue.

A partial aim of the project is to find an optimal alternative route for all types of vehicles. Capacity and traffic delay are two of the used parameters in the decision-making process. Capacity defines the throughput of road and traffic delay which is based on the level of service. Therefore, the values are derived from the state-of-the-art materials. The data 
are usable for macroscopic models where a large number of parameters is considered. For a project on the microscopic level, specific model of traffic delay and adverse weather impact needs to be derived.

\section{ACKNOWLEDGEMENTS}

This research has been supported by the Ministry of the Interior of the Czech Republic, research project No. MV-75143-7/OBV-2010 Operative travel demand management in case of evacuations and extraordinary events on the transport network.

\section{REFERENCES}

Alhassan, H. M., Johnnie, B. E., 2011. Effect of Rainfall Intensity Variability on Highway Capacity. European journal of scientific research, 49 (1), pp. 18-27. ISSN 1450-216X.

Český hydrometeorologický ústav, 2011. ČHMÚ Nowcasting webportal [online]. [cited 201210-03]. Retrieved from: http://www.chmi.cz/files/portal/docs/meteo/rad/inca-cz/index.html (in Czech)

Český hydrometeorologický ústav, 2012. Mapy charakteristik klimatu [online]. [cited 201210-03]. Retrieved from: http://www.chmi.cz/portal/dt?menu=JSPTabContainer/P4_Historicka _data/P4_1_Pocasi/P4_1_3_Mapy_char_klim (in Czech)

ČSN 73 6101, 2004. Projektování silnic a dálnic. Praha: Český normalizační institut. (in Czech)

ČSN 73 6101, 2009. Změna Z1, Projektování silnic a dálnic. Praha: Český normalizační institut. (in Czech)

ČSN EN 1991-1-3, 2012. Změna Z4, Eurokód 1: Zatížení konstrukcí - Část 1-3: Obecná zatížení - Zatižení sněhem. Praha: Český normalizační institut. (in Czech)

HCM, 2010. Highway Capacity Manual (HCM 2010), 5th Edition. Washington, D.C.: Transportation Research Board. ISBN 978-0-309-16077-3.

Hranac, R., Sterzin, E., Krechmer, D., Rakha, H., Farzaneh, M., 2006. Empirical Studies on Traffic Flow in Inclement Weather [online]. Washington, D.C.: U. S. Department of transportation, FHWA [cited 2012-10-04]. Retrieved from: http://www.ops.fhwa.dot.gov/ publications/weatherempirical/weatherempirical.pdf

Chung, E., Ohtani, O. Warita, H., Kuwahara, M., Morita, H., 2006. Does Weather Affect Highway Capacity? In 5th TRB International Symposium on Highway Capacity and Quality of Service. Yokohama.

Jeihani, M., Lawe, S., Conolly, J. P., 2006. Improving Traffic Assignment Model Using Intersection Delay Function. In $47^{\text {th }}$ Annual Transportation Research Forum proceedings, New York, March 23-25, 2006. 
Lammi, J., 1997. Photoperiod Calculator. The Scout Report for Science \& Engineering [online]. [cited 2012-10-15]. ISSN 1533-144X. Retrieved from: https://scout.wisc.edu/Archives/SPT--FullRecord.php?ResourceId=2283

National Academic Press, 2004. Where the Weather Meets the Road: A Research Agenda for Improving Road Weather Services. Washington, D.C.: National Academies Press. 174 p. ISBN 03-095-2980-8.

Ortúzar, J. D., Willumsen, L. G., 2011. Modelling Transport, 4th Edition. West Sussex (United Kingdom): John Wiley. 606 p. ISBN 978-0-470-76039-0.

Ředitelství silnic a dálnic ČR, 2009-2010. Dopravní info.cz [online]. [cited 2012-10-03]. Retrieved from: www.dopravniinfo.cz (in Czech)

Tanner, J. C., 1952. Effect of Weather on Traffic Flow. Nature: the international weekly journal of science, 169 (4290), p. 107. ISSN 0028-0836.

TP 189, 2012. Stanovení intenzit dopravy na pozemních komunikacích (II. vydání). MD-OPK č.j. 279/2012-120-STSP/1. Plzeň: EDIP s.r.o. (in Czech)

TP 225, 2010. Prognóza intenzit automobilové dopravy. MD-OPK č.j. 434/10-120-STSP/1. Koura Publishing. (in Czech)

The article was produced under the support of the project Transport R\&D Centre (CZ.1.05/2.1.00/03.0064) 